Textos 


\section{As luzes do mercado se apagam: as falsas promessas do neoliberalismo ao término de um século em crise}

\section{ROBERT KURZ}

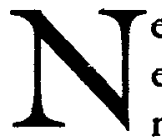

enhuma dúvida: a falência econômica do socialismo de Estado estimulou enormemente todas as ilusóes do Ocidente sobre si mesmo. A consciência crédula na economia de mercado, pouco menos ideológica que a sua contrapartida falsificada na prática, encara-se como vencedora da história. Parece já ter sido quase esquecido que o neoliberalismo dos anos $\mathbf{8 0}$ foi, ele próprio, uma reação às crises econômica e social do Ocidente, que já ameaçam há mais de uma década. A emergencial bandagem em torno da própria testa, que até agora pouco ajudou, é estilizada subitamente como se fosse um brilhante louro da vitória, por ter-se afundado na poeira um outro combatente da história da modernização. Agora, no entanto, o Ocidente e um mundo economicamente ocidentalizado estáo sozinhos consigo, e seria adequado recolocar sob o microscópio as receitas do neoliberalismo, bem como a rcalidade a que se referem.

Que há tempos estamos diante de uma crescente crise econômica mundial, não é negado sequer por muitos neoliberais. Eles fundamentam tal crise, no entanto, não nas contradiçóes do próprio sistema de mercado, mas primeiramente em erros de ordem institucional, econômica e ideológica, que teriam sido cometidos por socialistas, keynesianos etc. A visão de mundo aí subjacente é de uma nobre simploriedade iluminista. $O$ discurso neoliberal pressupóe que todas as economias nacionais poderão prosperar por toda a eternidade dentro do sistema da economia de mercado, bastando seguirem o modelo correto de ordem e desenvolvimento (muitas vezes designado inclusive como natural) de uma economia maximamente privatizada e não-regulamentada, na qual o Estado se restrinja a manter a estabilidade do valor da moeda (política financeira monetarista) e a garantir law and order. Tanto o Ocidente em 
crise, que teria ficado doente por excesso de intervencionismo estatal, despesas sociais e deficit spending, quanto também as sociedades do Oriente e do Sul, ainda náo suficientemente formadas em termos de economia de mercado, precisariam táo somente fazerem as suas tarefas domésticas, em termos de uma política da ordem no sentido dos Chicago-Brothers de Milton Friedman, para que paz e prosperidade passassem a imperar no One World do dinheiro global.

O platonismo modelar dessa ideologia choca-se, no entanto, cada vez mais com as condiçóes sociais e históricas concretas, nas quais devem ser implementadas - de novo ou até pela primeira vez - a concorrência, a privatização e a desregulamentação. Só aparentemente chegam a ter voz essas condiçōes quando, desde há algum tempo, o modelar platonismo da economia de mercado é flanqueado por uma doutrina político-cultural institucionalizada, entre outros fatores devido à teoria de Mancur Olson (1). A teoria olsoniana, inicialmente desenvolvida em função dos problemas da própria economia de mercado ocidental, afirma, em seu cerne, que a consolidação política e cultural de grupos de interesse, os quais bloqueiam inovaçóes e acessos ao mercado, acaba inibindo o crescimento econômico das sociedades. Para os que acreditam na economia de mercado, isso quer dizer que a liberdade precisa ser treinada, que precisa ser desenvolvida uma cultura da concorrência e da responsabilidade pessoal adequada ao mercado. Portanto, essa doutrina à base de modelos, ahistórica e cega diante dos condicionamentos estruturais, é estendida apenas à disposição cultural dos sujeitos e às suas formas de articulação política.

Também para as relaçōes entre as diferentes economias nacionais entre si, o neoliberalismo tem novamente a oferecer a concepção de um modelo teórico e, naturalmente, é claro, uma concepção de livre-comércio. Assim como precisa-se desregulamentar para dentro, também precisa-se para fora. Exige-se a abertura dos mercados (ainda que nem sequer os governos de inspiração neoliberal tenham se atido a isso), e a orientação para a exportação mediante vantagens comparativas recíprocas, o que pretende arrancar até mesmo o antigo Terceiro Mundo do desastre em termos de desenvolvimento. Seremos levados, portanto, para épocas maravilhosas se tudo se comportar assim. Infelizmente, no entanto, os inovadores neoliberais pecam contra o primeiro mandamento de sua própria doutrina, pois mostram-se extraordinariamente sem sucesso. Após menos de uma década, já deixou de brilhar de novo a estrela dos reaganomics e do thatcherismo. Em termos de economia, restou um monte de ruínas. Também no Leste e no Sul as reformas econômicas transcorrem de forma mais que decepcionante. A grosso 
modo, a pobreza foi drasticamente multiplicada, não reduzida. Não bastando isso, também a crise do Ocidente continua avançando. $O$ que parece estar à porta é menos a recuperaçáo no Oriente do que, antes, a queda no Ocidente. O rei - o sistema de mercado - está nu. Ao invés, porém, de se reconhecer abertamente esse lamentável fato, fica-se cosendo, obsessivamente, em torno de uma mitologia de sucessos, enquanto a economia mundial de mercado, que ficou sem concorrência alguma, vai gerando uma catástrofe após a outra.

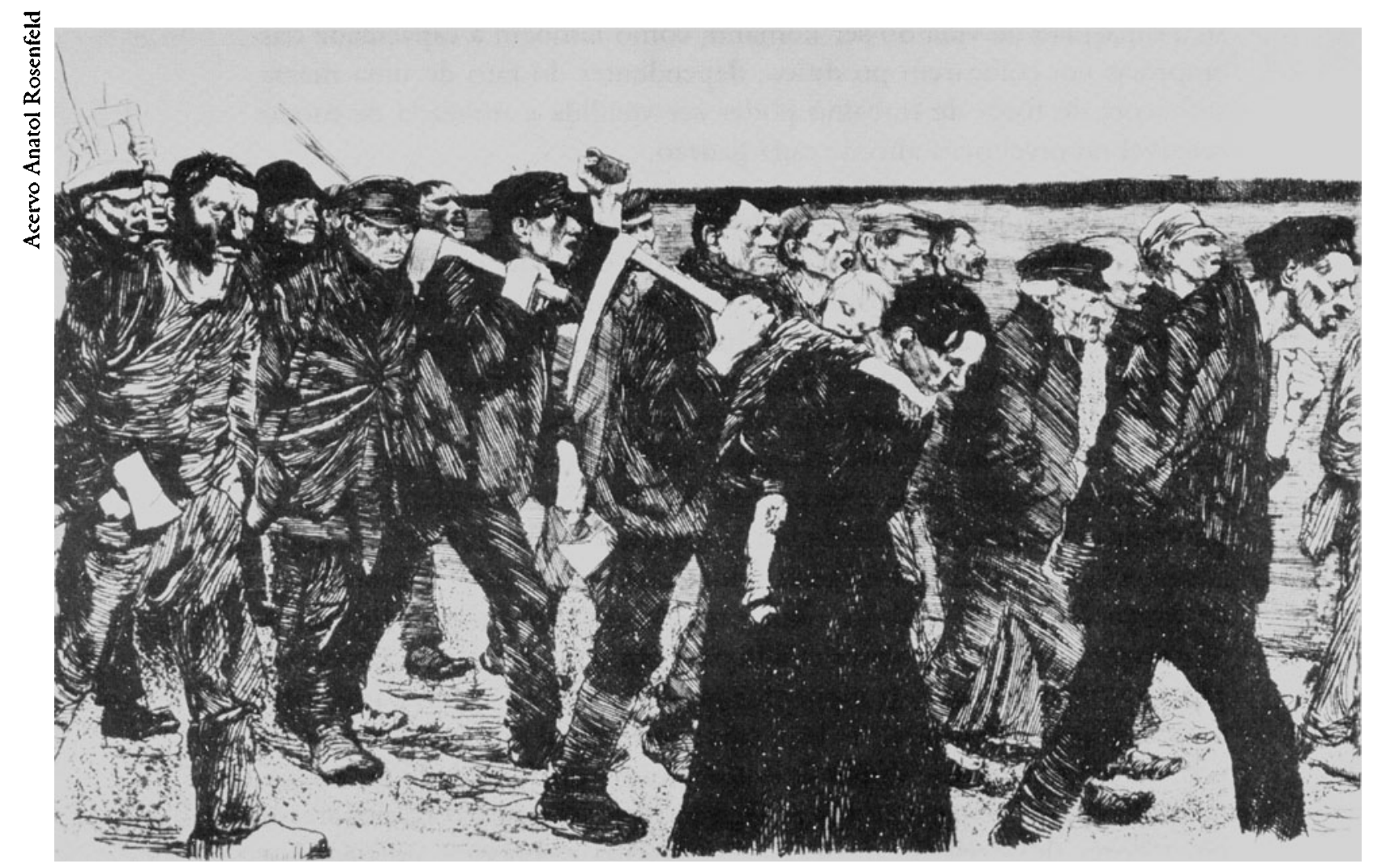

A marcha dos tecelãos, por Käthe Kollwitz.

Contradições inerentes à sociedade de mercado

A crise que amadurece não é mais qualquer daquelas crises cíclicas, como são conhecidas desde o processo de ascensáo e preponderância dos modernos sistemas de mercado, mas uma crise estrutural que vai mais fundo, na qual as contradiçóes intrínsecas à economia de mercado surgem à tona. Esse dilema estrutural, insolúvel em termos de mercado, 
pode ser descrito em dois níveis. Por um lado, mostra-se uma contradição interna entre racionalização empresarial e poder aquisitivo da sociedade, contradição que é constitutiva para mercados de colocação de produtos. $O$ princípio da concorrência substitui sucessiva mão-de-obra por agregados materiais de origem científica: uma intensificaçáo de capital, a crescer secularmente (isto é, capital cada vez maior em termos de equipamentos para cada lugar de trabalho ou cada máo-de-obra), confronta-se e defronta-se com uma decrescente intensidade de trabalho.

Por outro lado, no entanto, o princípio do salário do trabalho torna não só a capacidad de vida do ser humano, como também a capacidade das empresas em colocarem produtos, dependentes do fato de uma massa suficiente de força de trabalho poder ser vendida e utilizada de modo rentável no nível mais alto de cada padrão.

Esta contradição interna do sistema, há muito já conhecida, foi, no passado, sempre compensada pelo fato de o modo de produção da economia de mercado expandir-se mais rapidamente do que a racionalização empresarial. Em última instância, a contradiçăo interna aflorava brevemente nas crises cíclicas. Desde os anos 80 , contudo, essa constelação modificou-se radicalmente. A revolução microeletrônica, com as suas recentes técnicas de robotização e comunicaçáo, possibilitou enorme quantidade de novas concepçóes de racionalização, tendo sido o miolo da ocupação de mão-de-obra, nos países desenvolvidos, derretido como neve ao sol. Tal processo está longe de ter acabado; sob a rubrica de produção sem adiposidades (concentração do investimento de custos no cerne lucrativo), ele entra atualmente em uma nova fase. Essa concepçáo comandada pelo computador procura diminuir, com a intensificação crescente do capital, o dispêndio empresarial absoluto de capital, por um lado, mediante diminuição drástica da profundidade no acabamento (repasse de parcela dos processos empresariais a fornecedores e prestadores de serviços, aos quais é repassada também a pressão dos custos e, por outro, emagrecimento das estruturas organizacionais remanescentes, até mesmo na administração, mediante uma liberação de força de trabalho. O núcleo remanescente de empregados precisa, então, aparecer sob alta densidade de trabalho, como selefẫo olímpica.

No início dos anos 90 , os 24 países da OECD contavam com cerca de 30 milhóes de desempregados. O desemprego estrutural de base (já independente de ciclos) andou se equilibrando, na Grá-Bretanha e na França, em torno de 3 milhões cada; na Alemanha, em cerca de 2 milhôes. $\mathrm{Na}$ indústria alemã ocidental, estáo previstas mais de 3 milhōes de demissóes até 1995; no setor de construção de máquinas, por exem- 
plo, o decréscimo de pessoal está avaliado em $200 \mathrm{mil}$, na indústria elétrica em $150 \mathrm{mil}$, na área da química e da mineração em cerca de 100 mil cada, e, no setor-chave da indústria automobilística, em 300 mil postos. Ao mesmo tempo, está-se diante de uma onda de racionalização burocrática. Mesmo os setores até agora menos intensivos em termos de capital passam a ser enxugados através de reestruraçóes; a política de empréstimos abrange bancos e seguradoras tanto quanto empresas estatais altamente deficitárias, como o transporte ferroviário e os correios. Essa massa monstruosa de força de trabalho posta fora de açáo já não pode mais ser - de um modo diferente das etapas anteriores de racionalização - reintegrada economicamente no mercado, pois a ampliaçáo do modo de produçáo ultrapassou o seu limite de saturaçăo. A incorporação dos setores tradicionais da produção agrícola, manufatura, gêneros alimentícios, pequeno comércio etc., na política de racionalização empresarial, foi concluída nos dois primeiros decênios após a Segunda Guerra Mundial e não mais dispóe de potenciais de reserva (Lutz, 1984). Novos ramos da produção, porém, já passam a integrar-se na intensificação do capital e da racionalização.

Além disso, a contradição inerente à economia de mercado mostra-se na relaçáo de, por um lado, processos de mercado entre pessoas privadas e, por outro, ampliações da infra-estrutura global da sociedade. Mediada pela concorrência, a cientificização da produçáo levou, por trás das costas da racionalidade empresarial, ao não intencionado efeito colateral de que o contexto das condições infra-estruturais da produção empresarial se expandiu mais rapidamente do que a própria produção. Somente nos anos $\mathbf{4 0}$ do século passado é que circulou na Alemanha, entre Nürnberg e Fürth, o primeiro trem; somente na metade do século foi inventada a telecomunicaçăo; apenas por volta da virada do século foi construída a maior parte da canalização nos novos aglomerados urbanos. Uma evolução semelhante ocorreu nas instituições educacionais e científicas, nos setores da saúde, da assistência social, da segurança social etc.

Enquanto a produção empresarial está condicionada ao êxito dos processos de mercado entre pessoas privadas segundo a lei da oferta $e$ da procura, os agregados infra-estruturais, porém, não podem ser levados avante segundo essa lei, ou entâo só com grande dificuldade, já que, por sua essência, eles são imediatamente de natureza social global e, a rigor, não constituem produção de mercadorias de produtores privados. É praticamente impossível querer organizar de modo cíclico, de acordo com o parâmetro da demanda de valores monetários, a canalização de água e esgoto, o sistema ferroviário, a rede de comunicação, o sistema 
de saúde ou as escolas e universidades. Por outro lado, a capacidade concorrencial de um país depende cada vez mais da eficiência funcional e do nível desses agregados. Se o contexto das condiçóes infra-estruturais começa a superar a finalidade empresarial a rigor pressuposta, tanto materialmente quanto também no valor, surge um problema que năo é mais solucionável em termos de economia de mercado. Nessa contradição é que também andou se arrebentando a demasiado ingênua ideologia anglo-saxônica da privatizaçáo dos setores públicos, cuja concretizaçáo nos Estados Unidos e Gră-Bretanha, durante a década de 80, conseguiu arruinar grandemente a infra-estrutura e enfraquecer de modo decisivo a posição desses países no mercado mundial.

As duas e interligadas contradiçóes intrínsecas à economia de mercado expressam-se na cada vez maior intensificaçáo de capital nas cconomias nacionais. A seus fatores pertencem nāo só os agregados materiais das empresas (parques de máquinas etc.), mas também os investimentos $\mathrm{em}$ infra-estrutura material $\mathrm{e} \mathrm{em}$ capital humano. Este último fator abrange, por exemplo, náo só os custos para educação, hospitais, aparelhos sociais etc., mas também os custos de manutenção de cada vez mais gente, que, por uma parcela cada vez maior parte de suas vidas, fica excluída da meta de valorizar-se o capital produtivo. Já que todos esses fatores náo se devem à filantropia, mas ao padrăo da concorrência mundial, eles também não podem ser impunemente reduzidos (ou mantidos em estado de subdesenvolvimento). Isso quer dizer que os custos prévios em capital financeiro para uma produçáo rentável crescem incessantemente, tanto na empresa individual quanto na totalidade social: cada vez mais empresas, bem como regióes e países inteiros, não mais saberăo como respirar: há de ser gerado um desemprego em massa cada vez maior. A espiral da crise da autocontradiçăo estrutural pốe-se a girar.

Os Estados e o sistema financeiro comercial procuram empurrar com a barriga a crise estrutural da economia de mercado, ao criarem um capital financeiro fictício, que não tem mais base em processos de geração de valor no capital produtivo. Isso é feito através dos mecanismos de crédito e através da especulação. O Estado suga dinheiro de poupanças através de empréstimos voluntários e compulsórios, que em parte não honra mais, ou deixa evaporar (zerando a dívida mediante perdas na moeda) ou financia-se diretamente através da impressora de notas de dinheiro. Os bancos financeiros jogam liquidez na sociedade, à medida que abrem as comportas da criaçáo de dinheiro no sistema bancário (queda da taxa de juros para empréstimos, desregulamentafăo dos mecanismos de controle, como, por exemplo, reservas cambiais mínimas 
etc.). Daí as empresas, bem como as pessoas físicas, já não investem de modo rentável os lucros disponíveis na especulação em açōes ou imóveis: assim que esta se encontra outra vez aquecida, conduz a monstruosas valorizações fictícias e transforma-se em incontrolável máquina de gerar dinheiro. Todos esses mecanismos, na década de 80, foram forçados pelo mundo inteiro em escalas diferentes, tendo encenado um boom aparente $\mathrm{e}$ improdutivo. A outra face do desemprego estrutural em massa, ou seja, o encolhimento dos mercados de colocaçáo de produtos, fica escamoteado através de um poder de compra improdutivo, criado artificialmente. Sobre isso é que repousava não só o boom do luxo dos anos 80, e com ele toda a conecta e leviana ideologia yuppie, mas também o crescimento generalizado do consumo governamental, a aparente capacidade de investimento de muitos empresários e uma grande parte dos rendimentos. Segundo estimativas, somente na Alemanha Federal devem existir, além do desemprego subvencionado, mais de 5 milhōes de empregos irregulares (mantidos indiretamente e, a rigor, já não mais rentáveis), que dependem de subvençóes da produção (por exemplo, da Comunidade Européia) ou náo mais correspondem ao último padrăo de racionalizaçáo.

A crise da reacumulação, jogada mais adiante e, a rigor, ameaçando desde o final da década de 70, mostra-se já nos sistemas financeiros nacionais e internacionais (2). O improdutivo processo de criação de dinhciro leva a desvalorização da moeda em parte até à hiperinflação periódica. A explosão da bolha da especulação, que em sua fase tardia ainda se alimenta apenas de crédito, conduz a ondas de bancarrotas e a enormes amortizaçóes. Não só nos dois crashes na bolsa, de 1987 e de 1989, os bancos de títulos tiveram de inventar desesperadamente liquidez, gastando toda a sua pólvora. As crises da dívida, interna e externa, dos Estados estão amadurecendo. Desde meados dos anos 80, ouvem-se os seus estalos nos sistemas bancários nacionais e internacionais na Escandinávia, no sul da Europa e na Inglaterra, nos Estados Unidos e no Japão, na América.Latina e no Oriente Próximo. Torna-se necessária uma açáo emergencial e de sustentaçáo após a outra. A crise financeira do pseudo-crescimento à base de endividamento rebate, desde 1991, diretamente na conjuntura mundial e, com isso, na ocupaçáo mundial de máo-de-obra. O movimento cíclico repercute negativamente, e muitas vezes reforçado por ressonância: limitaçăo estrutural do sistema de mercado, retração periódica e crise financeira da endividada liquidez aparente conjuminam-se na direçăo de uma crise global. Uma maré mundial de retrações de encomendas, estornos, drásticas perdas de lucros e paralisaçôes de atividades ameaça agudizar-se no sentido de uma 
depressão generalizada, em que a olho nenhum hão de ser poupadas as lágrimas.

\section{História do mercado mundial \\ e intermediação no mercado mundial}

O problema fundamental da crise é, por certo, moderado através da intermediação no mercado mundial. Justamente nesse nível é que o neoliberal platonismo de modelos passa mais vergonha. Todas as sociedades hodiernas, sem exceção, são compatíveis com o mercado mundial, e isso significa que cada vez menos a sua graça e a sua desgraça são determinadas somente por mecanismos internos de regulamentaçáo de ordem política. A crescente influência do mercado mundial sobre a produção social interna pode ser, a grosso modo, exposta em três fases:

- Ia fase: da época dos descobrimentos e da primeira colonizaçáo até a metade do século XIX, destacaram-se inicialmente, tendo a Inglaterra como ponta de lança, algumas poucas economias nacionais do Ocidente. Nelas, o modo de produção para o mercado náo havia, nem de longe, conseguido impor-se plenamente, de maneira que as crises ainda não podiam repercutir no modo de reproduçáo da sociedade toda, que continuava grandemente determinado.pelo caráter agrário e de subsistência. Proporcionalmente estreita era a rede mundial de mercados, ainda muito marcada pelo caráter colonial.

- 2a fase: da era dos pais da pátria até o final da Segunda Guerra Mundial, ou até o final dos anos 60, surgiu uma série de novas economias nacionais. Aos poucos, inclusive, o mundo foi significativamente descolonizado, e o modo de produção da economia de mercado expandiu-se para a totalidade da produção interna das sociedades. As crises atingiram, por isso, massas populacionais muito maiores que antes, como o demonstrou sobretudo a depressáo mundial de 1929-33. Adensa-se a interligaçáo mundial dos mercados. O mercado internacional continuou sendo, porém, um espafo funcional secundário, enquanto o peso principal das relaçóes econômicas concentrava-se nos mercados nacionais internos.

- 3ㄹ fase: da pax americana do pós-guerra até o final do século $\mathrm{XX}$, o modo de produçáo para o mercado passou a romper o âmbito das economias nacionais, para gerar toda uma rede internacional dos 
mercados. Esse processo ainda está em andamento e transcorre diante dos nossos olhos. Os mercados internos a olhos vistos perdem o seu caráter relativamente fechado, o mercado mundial ou grandes mercados regionais de caráter mundial tornam-se o espaço funcional imediato de um número cada vez maior de sujeitos econômicos. Mesmo as maiores economias internas estáo cada vez mais sujeitas a tal modificação: até na economia dos Estados Unidos, tradicionalmente orientada para dentro de si própria, duplicou, só entre 1965 e 1980, a participação do comércio exterior no produto interno bruto. Com isso, porém, a crise também ameaça transformar-se em crise global e geral, em que já não poderá mais ser superada a limitação estrutural da contradição intrínseca à economia de mercado.

Do ponto de vista do mercado, portanto, não se trata apenas de um princípio estrutural ou de ordenamento, mas simultaneamente de um processo de globalização. A escala crescente na formação da rede mundial da economia de mercado foi tornada possível desde o surgimento das linhas regulares dos grandes vapores e a criaçăo das ligaçốes telegráficas, através do progresso na técnica de transportes e comunicaçăo. $\mathrm{Na}$ primeira fase, expandiu-se apenas o comércio mundial. $\mathrm{Na}$ segunda, acresceu-se a exportação extensiva de capital, isto é, setores inteiros de produção foram instalados em outros países como capital, forçando a expansão do modo de produção para o mercado. Na terceira fase, a exportação intensiva de capital, ou seja, a divisáo internacional de processos de produção, arrebentou definitivamente a cápsula das economias internas. A isso corresponde, desde os anos 70, a formaçăo de mercados financeiros internacionalizados (mercados monetários europeus), que acabaram ficando fora do controle dos sistemas nacionais.

Na história do mercado internacional, trata-se, portanto, de etapas de desenvolvimento na geraçáo do capital mundial imediato. Isso significa, porém, que se vai superando a coexistência, até agora vigente, de diversas fases de evolução não-sincrônicas e, com isso, a existência simultânea de diferentes níveis de produtividade e rentabilidade. Constitui-se um padrão internacional, que passa a ser concretizado nos mercados financeiros globalizados através de terms of trade (relação de preços de importação e exportação) e das taxas de juros. Isso significa o fim para os retardatários históricos, porque eles já não podem mais financiar a maior parte dos custos de capital no padrăo exigido pela intensificação de capital nos planos empresarial e infra-estrutural. Por isso, eles sáo os primeiros a serem jogados na crise pela contradiçăo estrutural inerente ao modo de produçáo para o mercado. Os êxitos temporários da industrialização recuperativa, que somente foram possíveis em espaços econô- 
micos internos relativamente compartimentados, acabam, no contexto da globalização, sendo tornados em grande parte novamente retroativos, sendo os antigos paises em desenvolpimento os primeiros a perderem o acesso ao sistema de crédito internacional.

A teoria tem se recusado até agora a refletir adequadamente essa correlação. Já que o discurso neoliberal não reconhece um entrave crítico no sistema de mercado, nem leva suficientemente em conta as mediações concretas no processo de mercado mundial (e suas conseqüências negativas), ele naturalmente não pode também levar a sério a questâo do perdedor. O problema do perdedor aparece como sendo apenas velativo, isto $e ́$, no sentido de Schumpeter $(1912,1950,1951)$, como destruifán produtiva de setores que se tornaram sem rentabilidade e que podem ser, em todo caso, substituídos por novos procedimentos, produçōes e empresas, de maneira que, diz-se, a economia como um todo acaba sendo inclusive até estimulada em sua prosperidade.

Se, no entanto, o capital mundial, assim que ele se constituíu, choca-se com a barreira estrutural da contradiçáo interna da economia de mercado (e isso através das mesmas forças produtivas que o criaram), surge então uma nova reciprocidade entre ganhadores e perdedores. $O$ estatuto de perdedor assume agora um caráter absoluto. Já que na escala global os efeitos da racionalizaçáo empresarial vão além da ampliação do modo de produção para o mercado, um estatuto de ganhador somente é ainda possível pelo fato de, em algum outro lugar, alguém ser absolutamente aniquilado. A relação entre ganhadores e perdedores, portanto, náo intermedia mais a reestratificafico de capital em procedimentos mais produtivos e setores mais modernos, mas torna efetiva a barreira estrutural de crise de todo o capital global mediante a absoluta eliminaçáo de capital, o que conduz à falência de países e continentes inteiros. Trata-se de um efeito-dominó, que começa nos retardatários históricos mais fracos em termos de capital e termina nas economias ocidentais mais fortes em termos de capital, de maneira que a crise.acaba sendo, por fim, sincronizada mundialmente apenas após uma fase mais longa de incubaçăo e evolução.

\section{Teoria do desenvolvimento e teoria da crise}

A fraqueza do neoliberalismo parece acabar sendo também a dos seus adversários da esquerda keynesiana e da socialista. Em última instância, isso não reside no fato de teoria do desenvolvimento e teoria da 
crise das esquerdas terem cristalizado em grande parte discursos separados (3). Enquanto as teorias da crise referem-se sobretudo aos conjuntos funcionais abstratos do capital em geral, continuando a posição axiológica fundamental da intermediação no mercado mundial a ser, apesar das análises empíricas de detalhes, um black box teórico, não se deve, portanto, referir mais a uma limitaçăo histórica absoluta da contradiçáo intrínseca à economia de mercado (4). Enquanto ela nem sequer deve ser mais apontada, as teorias do desenvolvimento buscam um modelo correto para a modernização $\mathrm{e}$ a industrialização das economias nacionais. Essas teorias, sobretudo os diferentes ramos das teorias da dependéncia nos anos 60 e 70, foram elas próprias formuladas no horizonte da problemática da recuperaçáo do atraso histórico e, nessa medida, dentro do horizonte da ascensão histórica do modo de produção da economia de mercado. Elas limitam-se geralmente a deduzir o subdesenvolvimento a partir de, em última instância, determinadas relaçōes de dependência de natureza política e neocolonial (preços injustos, monopolismo, pressões militares, instalação de regimes dóceis etc.). Mesmo análises puramente econômicas têm sido, sobretudo, assim, fundamentadas menos no plano teórico sistemático do que, muito mais, no plano teórico subjetivo e da dominação (em termos de política nacional ou sociologia de classe).

Essa politizafáio comporta-se - numa ironia involuntária - como um espelho do platonismo de modelos conforme a ordem política do discurso neoliberal hodierno, talvez não tendo sido, por isso, tão difícil para muito teórico a passagem para a outra margem ideológica. Desde as bancarrotas do socialismo de Estado e da antiga estratégia de uma política de substituição de importaçóes flanqueada pela economia estatal (sobretudo a Escola da CEPAL na América Latina), até mesmo antigos teóricos do desenvolvimento, que eram críticos do capitalismo, acabaram se abrindo para o neoliberalismo: na verdade, menos com relação ao papel do Estado, e mais no sentido de uma maciça integraçáo no mercado mundial e de um voltar-se para a exportaçáo, tomando por modelo, através de analogismos históricos, a história do desenvolvimento europeu do século XIX, num conformismo com a economia de mercado, sem se voltarem de modo adequado, enquanto sistema de referência, para o processo de globalização, ora já irreversivelmente desenvolvido (5).

Isso fizeram, pelo contrário - ao menos em parte e da boca para fora -, algumas das teorias críticas da dependência, com o conceito central de sistema mundial (6). Mesmo assim, também esses prolegômenos ficaram na tematização de uma troca desigual, assimétrica entre centros 
e periferia para derivar daí uma transferência de valores, supostamente irregular ou ilegítima, do Terceiro Mundo para as metrópoles. Também essas primeiras tentativas de uma teoria de um sistema mundial (não por acaso antes historicamente orientadas), por conseguinte, ainda são formuladas a partir de uma perspectiva de um desenvolvimento a ser recuperado, sem conseguirem integrar a questão de um limite crítico do sistema como um todo: elas permanecem fixadas univocamente na contradiçáo entre desenvolvimento e subdesenvolvimento (Norte e Sul), dentro do horizonte de uma socialização pelo mercado, de maneira que as contradiçóes intrínsecas ao sistema de mercado em sua base produtiva aparecem somente na forma superficial de um modelo global de circulaçáo. A questão dos recentes países em desenpolvimento, um penhor do discurso neoliberal, só vem sendo assumida com dificuldade, através do superficial conceito de paises semiperiféricos (com o qual seus adversários também se banquetearam a valer), pelas teorias críticas de um sistema mundial até agora existentes.

Em tudo isso, em primeira linha, não se trata por certo de fraquezas teóricas subjetivas, mas sobretudo de, como que debaixo dos olhos do observador científico, ter-se alterado o sistema global de referência. $O$ denominador-comum entre neoliberais e teóricos da dependência, de referirem-se igualmente à segunda fase da concluinte redeficação mundial em termos de economia de mercado, enquanto a terceira fase do capital mundial imediato somente veio plenamente à luz na década de 80, determinando hoje o processo, preparando-se, entrementes, para provocar uma nova qualidade de crise, no processo sistemático de globalização. Torna-se necessário, portanto, um novo modo de abordagem, que pense simultaneamente, num metanível, a teoria do desenvolvimento e a teoria da crise. Aí, o conceito de sistema mundial precisa ser repensado de modo mais profundo, não mais apenas enquanto modelo de circulaçáo na economia de mercado - como era adequado à fase das economias nacionais ligadas principalmente por comércio e exportaçáo simples de capital -, mas enquanto modelo de crise do capital produtivo transnacional, em que as contradiçóes imanentes a esse modo de produção e sua temporária suspensão através da criação não-produtiva de dinheiro reaparecem agora em nível mais global.

\section{As perfídias do salário barato e da orientação para a exportação}

No séquito dos pioneiros do pensamento neoliberal, de um modo 
quase unânime, é então recomendado, para as até agora economias de crise e bancarrota, uma urgente abertura para o mercado mundial: elas deveriam procurar nichos globais para si, a fim de, mediante especialização seletiva, encaminharem um desenvolvimento induzido pela exportaçāo e, daí, um milagre económico. Explícita ou implicitamente, está por trás disso o conceito de salário barato, com o qual devem ser estimuladas as ofensivas de exportaçăo dos países em desenvolvimento ou em crise, cuja fraqueza de capital procura-se fazer de conta que não existe. Ora, o salário barato, ou melhor, o salário de fome, não é naturalmente nada de novo. Já a industrialização européia deu sua partida com o motor da acumulação, uma concepção que hoje é envergonhadamente favorizada, ou ao menos embelezada, até por ex-esquerdistas teóricos do desenvolvimentismo. Mas essa história não se deixa repetir, já que a intensidade do capital de produçáo rentável e a racionalização empresarial têm se desenvolvido continuamente desde então, ampliadas $e$ intensificadas até o padrão mundial contemporâneo. $O$ salário barato torna-se necessariamente um modelo em extinçăo. Nisso, em última instância, é que andaram fracassando também as tentativas até hoje feitas de recuperar o desenvolvimento perdido no século $\mathrm{XX}$, o socialismo de Estado e os regimes de modernizaçáo no Sul, que só conseguem suster-se por algum tempo mediante salários baixos e jornadas longas de trabalho. Subjacente a isso estavam doutrinas do isolamento com relação ao mercado internacional, substituição de importaçóes e políticas de desenvolvimento autocêntricas. Mas por que deve, afinal, o mesmo fato do salário barato, ligado agora à doutrina de orientaçáo para a exportação, levar a melhores resultados se a concorrência global, ao mesmo tempo, leva adiante a racionalização de intensificar o capital?

A prova disso forneceram supostamente o Japáo e os tigres asiáticos, que vêm sendo elogiados até não mais poder como novos modelos de sucesso. Na boca dos neoliberais, esse elogio soa bastante estranho, pois tanto o Japáo como também os outros newcomers do leste asiático trabalharam desde o começo com fortes elementos de dirigismo estatal, com planejamento, subvençóes etc., e continuam assim procedendo até hoje. Inclusive a própria story do sucesso precisa ser posta em dúvida. Por razóes históricas, o mito do Japão não cabe como comparação, pois a industrialização japonesa começou quase ao mesmo tempo que a alemã, em pleno século XIX, o que ainda possibilitou buscar uma recuperação. Depois da Revolução de 1867, já na seguinte Era Meiji passou a ocorrer uma rápida modernização e industrialização. Sem base industrial, o Japão não teria podido vencer a guerra contra a Rússia em 1905 nem atacar os Estados Unidos na Segunda Guerra Mundial. Portanto, o Japão dificilmente pode servir como mensuração para um desenvolvi- 
mento recuperativo exitoso sob as condiçōes bem diversas do final do século XX.

Apesar desse ponto de partida historicamente muito melhor, até mesmo o Japão precisa ainda hoje produzir com elementos de salário vil. Nessa medida, o êxito japonês repousa sobre pés de barro. Segundo um estudo da Câmara Alemã de Indústria e Comércio (DHIT), de janeiro de 1993, a produtividade técnica no Japão está em parte até hoje, na média dos setores e das empresas, significativamente abaixo da alemã. As vantagens japonesas em termos de custo repousam, por um lado, nas jornadas de trabalho extremamente longas; por outro lado, o grau de automação altamente intensivo em termos de capital na fase final da montagem dentro das grandes empresas japonesas leva a não perceber, contudo, que estas sugam os seus fornecedores até a última gota, uma tendência que, entrementes, pode ser observada também na Europa, onde ela está longe, porém, de alcançar as circunstâncias japonesas. $\mathrm{O}$ sistema Shitauke de empresas fornecedoras dependentes, que é característico para a indústria de exportação japonesa, não só funciona à base do paternalismo, como também é muito mais profundamente escalonado que na Alemanha ou nos Estados Unidos: nos níveis de ordenaçáo em forma de pirâmide, milhões de trabalhadores, mal pagos e quase sem direitos, produzem partes de automóveis e de aparelhos eletrônicos sob condiçōes não raramente pré-diluvianas. Assim, também a dependência exportadora da economia japonesa é expressa de modo insuficiente pela quota de exportação nominal. Como a geração de valor no produto final é medida segundo critérios do mercado mundial, capta-se de maneira incompleta o processo japonês interno de formaçáo de valor, que contém grandes massas de trabalho subprodutivo, especialmente nos subsistemas de fornecedores voltados para a exportação. Trabalham, portanto, muito mais pessoas para a exportação do que a quota de exportação permite supor. Essa correlação pode ser também medida pelo fato de o nível interno de preços e o nível externo divergirem entre si: os produtos japoneses são bem mais baratos no mercado internacional do que no próprio mercado interno.

Ao mesmo tempo, isso significa que o Japão concorre, ao menos em parte, com elementos que fazem lembrar, de modo suspeito, as condiçốes existentes nas atuais economias em bancarrota, embora repouse numa organização especialmente refinada na combinação com elementos de high-tech. Enquanto a depravaçăo social no Ocidente decorre do desemprego estrutural, no Japão ela ainda é um componente estrutural arcaico da própria organizafáo do trabalbo. A concepçáo japonesa primeva de producâo enxuta funciona, por trás da fachada da alta auto- 
matizaçáo, principalmente por meio do dumping social na fase de pré-acabamento. Os imitadorés ocidentais parecem náo notar que seguem aí um modelo em extinção, que sob essa forma não é mais socialmente concretizável na Europa. A reaçăo ocidental somente pode ser, a longo prazo, uma concentração de capital e uma racionalizaçáo à base de intensificação de capital nas indústrias fornecedoras, o que não somente há de continuar elevando o desemprego estrutural na Europa e na América do Norte, como também ameaça aniquilar a vantagem japonesa nos custos a partir de sua combinação de bigh-tech à base de intensa ciência mais capital na fase final de montagem. Exatamente nessa perspectiva é que o Japão se debate hoje com os limites do seu modelo.

A consequiência năo foi nem é a superação da estrutura do salário barato, o que significaria renunciar à vantagem nos custos, mas a sua transferência para um território estrangeiro vizinho. Ao menos em parte, o ponto de partida para a industrializaçáo na Coréia do Sul proveio desse problema de exportação dos japoneses, que ainda hoje săo os principais fornecedores de bens de investimento e componentes para a aquele país, ocupando parte da indústria nos tigres asiáticos através do achatamento salarial. A Coréia do Sul, portanto, precisa depender, bem mais que o Japão, da vantagem nos custos decorrente do salário barato.

Através da pressão da concorrência no mercado mundial, inclusive para a Coréia do Sul, coloca-se, porém, cada vez mais o caráter precário dessa vantagem nos custos, uma vez que movimentos sindicais e reivindicações sociais passam também a exercer pressão desde dentro. $O$ resultado, no entanto, não é um desenvolvimento direto na direção do estado social fordístico, como na Europa. É verdade que o nível salarial avançou com a maior taxa de crescimento de toda a Ásia: só entre 1986 e 1989 , a remuneração média por hora de trabalho cresceu em $28 \%$. Justamente por isso, no entanto, a indústria sul-coreana precisa, por um lado, introduzir ela mesma processos de automatização com capital intensivo, mas, por outro, desviar-se para países vizinhos de salário baixo, como Vietnã, Tailândia e República Popular da China. A ocupação industrial em massa na Coréia do Sul, portanto, não foi de maneira alguma exitosa: o país ainda se dicotomiza em segmentos empregados pela indústria exportadora e em populaçóes pobres. Apesar de alguns empreendimentos, também a infra-estrutura continua insuficiente (assim, por exemplo, apenas $28 \%$ das residências estáo ligadas à canalização).

Todo esse discurso em torno de uma já exitosa luta pela recuperação do atraso histórico em forma dos assim chamados NIEs ou NICs (New Industrialized Economies/Countries), cujo modelo querem que seja 
a Coréia do Sul, tem de ser considerada apressada e superficial. Apesar das altas taxas de crescimento, o produto social bruto sul-coreano per capita, no início da década de 90 , não está mais elevado que o de Portugal, mas encontra-se abaixo inclusive do da Grécia (dois países periféricos tradicionalmente de estrutura fraca e ainda fortemente marcados pelo setor agrário): alcança apenas cerca da metade do PIB iraquiano, espanhol ou israelita, raspa um quarto do norte-americano ou alemão $\mathrm{e}$ somente um quinto do japonês (sendo este último certamente manipulado através da estrutura de preços) (Banco Mundial, 1992). Já que grande parte do PIB decorre de uma industrialização exportadora feita à base de salário baixo, ele não pode sequer valer como indicador para o poder interno de compra em massa, que, apesar das elevaçóes salariais, ainda se encontra muito baixo. Assim, uma reorientaçáo para uma demanda interna fortalecida "somente seria possível com grandes dificuldades na Coréia do Sul, estando a economia sul-coreana ainda em fase de desenvolvimento induzido pela exportação e, por exemplo, as grandes elevaçốes de salário nos últimos anos não trazerem aquele impulso na demanda interna que possa compensar perdas na exportação" (Pohl, 1991). Essas observaçóes não são, de maneira alguma, maldosas, unfair, pois, sob o ditado da globalização, a escala de mensuração não pode mais ser um pretérito estágio de desenvolvimento da Europa, mas tão somente o contemporâneo, do capital mundial, que está se constituindo de um modo imediato.

Tudo isso vale em ainda maior proporção para os grandes Estados do ASEAN (Tailândia, Malásia, Indonésia e Filipinas) e para a República Popular da China. Nas famosas zonas de economia especial da província costeira no sul chinês, Guandong (Chenzhen, entre outras), não parece haver maciça capacidade aquisitiva, quando as forças de trabalho de lá são descritas por neoliberais ocidentais com esperançoso júbilo: "Trabalham nove horas por dia, seis dias por semana e têm duas semanas de férias por ano. Passam a noite em dormitórios, oito em cada quarto, dois beliches na parede esquerda e outros dois na direita, com um baú para os objetos pessoais, e o rolo individual de papel higiênico ao lado do travesseiro. Eles fazem caixas e pulseiras de relógio para um fabricante de relógios de Hong-Kong, por um fraçáo dos custos na colônia da Coroa" (Afheldt, 1993).

\section{O século pacifico não acontece}

O reduzido poder de compra interno dos NIEs, que, ao mesmo 
tempo, representa a principal base do êxito em sua exportação, exclui a longo prazo uma capacidade maior de importação. À primeira vista, essa constatação pode ser contradita pelo fato de a Coréia do Sul e a maioria dos países do sudoeste asiático recaírem sempre em balanços comerciais deficitários. Tais déficits, no entanto, resultam primeiro exclusivamente do intercâmbio com o Japão; segundo, comportam quase tão-somente a importação de bens estratégicos de investimento e de componentes para a respectiva indústria de exportação, porém pouco do largo espectro de bens de consumo duráveis (automóveis, aparelhos domésticos e de diversão), bens de consumo imediato etc. Os valores exportados, portanto, em grande parte são constituídos por máquinas importadas e produtos semi-acabados (extremada é essa relação, por exemplo, na Indonésia, onde, em 1990, três quartos dos valores exportados resultavam de valores importados). Assim, também a Ásia oriental não há de se transformar no esperado novo mercado de colocação de bens de consumo em massa para o Ocidente, a América Latina ou a Europa oriental. Pelo contrário, a orientação estruturalmente unilateral no sentido da exportação conduz a uma concorrência repressiva nos mercados internacionais. Portanto, a maré de exportaçóes do oriente asiático para a Europa ocidental quase arruinou a indústria de mineração e a construção de navios, a indústria têxtil e a de calçados. Também os produtores europeus orientais foram arrasados pela concorrência em muitos sctores, até mesmo na indústria-chave da construção de máquinas. Em última instância, não resulta disso a bancarrota do socialismo de Estado. A República Democrática Alemã, na década de 80 , perdeu para os concorrentes asiáticos a sua tradicionalmente elevada participaçáo em máquinas ferramenteiras, um fator essencial para o colapso do seu comércio exterior. Tanto mais difícil se torna descobrir onde os reformistas da Europa oriental vão buscar o seu otimismo em termos de economia de mercado: a quem querem eles, afinal, arrasar através da concorrência, e com que meios?

O crescimento unilateral da exportação dos newcomers asiáticos orientais, no entanto, repousa sobre pernas minguadas demais. A força somente é ostentada na aparência que, todavia, se deixa, afinal, desmascarar como fraqueza. Uma força saudável no sentido capitalista só pode ser alcançada, a longo prazo, mediante crescimento, no qual forças internas e externas se equilibram. Capacidade exportativa deve poder aparecer como capacidade importativa, portanto, devendo repousar numa relação comparativa recíproca. O baixo salário no contexto de uma estrutura exportativa unilateral não é vantagem comparativa alguma, mas um abuso com relação à respectiva teoria. A longo prazo, tal vantagem a curto prazo acaba conduzindo à eclosão de crises estruturais. Isso não 
é percebido pela maioria dos analistas, que, com arrogância positivista, apenas levam em conta em seus cálculos taxas de crescimento nominais das economias nacionais, sem se preocuparem muito com a conexão estrutural no sistema internacional. Encarada deste ângulo, a muito citada prognose de um século de paz aparece apenas como uma super bolha de sabão, pois a base do milagre asiático oriental revela-se, pelas razóes citadas, insustentável em três níveis.

Primeiro, ela é estruturalmente dependente da vantagem nos custos decorrente do salário baixo, o que não consegue, no entanto, ser socialmente mantido nem consegue concorrer, mesmo a médio prazo, com a cientificização intensificadora de capital. $O$ rápido movimento em dominó, do Japão para a Coréia do Sul e para os outros tigres asiáticos, daí para os grandes Estados do ASEAN e para o continente chinês, aponta já para a crise e o término desse modelo. Uma sistematizafão fordística, de estruturas sociais diferenciadas de reprodução, capaz de perdurar a longo prazo, não se consegue, porém, concretizar desse modo (7). Abandonar a estrutura do salário baixo, porém, seria fazer arrebentar a bolha de sabão.

Segundo, a orientação exportadora dependente de salário baixo move-se dentro de um circulo deficitário intra-asiático: todos os newcomers acumulam déficits com relação ao Japão, tanto nos balanços comerciais quanto nos balanços de capital, que não decorrem, no entanto, de importaçōes para consumo em massa, mas da importação de bens de capital. Isso significa que, ao mesmo tempo, os setores centrais da indústria japonesa, na área automobilística, eletrônica e ótica, não podem desviar-se em larga escala para os mercados asiáticos, erigindo neles um império mercantil auto-sustentável. $O$ boom do leste asiático, em última instância, não é senão o precário prolongamento da unilateral $(\mathrm{e}$, por isso, altamente vulnerável) ânsia exportatória japonesa.

Terceiro, o aparente milagre da Ásia oriental como um todo (isto é, com a inclusão do Japão) mostra ser - para o bem e para o mal dependente de fluxos unilaterais de exportação para os Estados Unidos e a Europa ocidental. Já que essa relaçáo náo repousa em uma parceria equiitativa, ela náo pode ser mantida através de capacidade aquisitiva norte-americana e européia regular, mas tão-somente através de um metacircuito deficitário global (sobretudo pelo Pacífico), cuja potência direta e indireta provém dos excessos de endividamento e das bolhas de especulação. O orçamento mundial da Sony, por exemplo, provém só em $28 \%$ do mercado pátrio japonês, enquanto $29 \%$ dele é oriundo dos Estados Unidos, 28\% da Europa e 15\% de outras exportaçōes. A quebra estrutural, já às vésperas do pretenso século pacifico, pode ser lida sobre- 
tudo na estrutura do comércio externo dos Estados Unidos. Em 1987, a exportaçáo dos Estados Unidos para a Europa e para a Ásia oriental era mais ou menos a mesma, cada uma com quase $30 \%$; a isso correspondiam bastante as importações da Europa (até com um leve superávit para os Estados Unidos), enquanto as importaçóes norte-americanas da Ásia oriental ascendiam a mais de $40 \%$ (e, entrementes, a quase a metade). A distribuição das exportaçóes dos Estados Unidos para a Europa e para a Ásia oriental tem se mantido constante desde 1975, tendo inclusive caído levemente com relação ao oriente asiático, enquanto a participação das importaçóes norte-americanas da Ásia oriental explodiu ascensionalmente, entre 1975 e 1987, de $29 \%$ para mais de $40 \%$ (8). Mais de dois terços do déficit comercial norte-americano, acumulado em dimensốes jamais antes vistas, provém somente do comércio com o Japão e com os quatro pequenos tigres asiáticos. A contradição interna do sistema de mercado, portanto, não é desmentida pelo notável êxito da Ásia oriental, mas apenas repassado adiante através de diversas e complicadas intermediaçóes. No fim, porém, essa contradição intrínseca deve reaparecer no metanível das mediaçóes globais, soprando a vela vital dos êxitos aparentes.

\section{Nenhum plano para grandes territórios e maiorias}

A crise do modelo neoliberal desregulado pela orientação para as exportaçóes não é mais nenhuma prognose teórica, mas já se mostra agora na prática para a maior parte do mundo. As falsas esperanças voltavam-se desde o início para os sucessos aparentes de alguns casos excepcionais, em países pequenos, com população relativamente reduzida, enquanto as grandes regióes globais dos antigos Segundo e Terceiro Mundos não eram nem são, evidentemente, reprodutíveis por meio da orientação para a exportação. Isso também é fácil de explicar. Somente países pequenos ou com populaçáo relativamente pouco expressiva podem especializar-se em nichos de exportação para o mercado mundial. Para os colossos populacionais, tal opção equivaleria, porém, à tentativa de enfiar um dinossauro na toca de um camundongo.

$\mathrm{Na}$ América Latina, estreito como uma toalha de mão, o Chile, que com seus 13 milhóes de habitantes mal chega à populaçáo da $\mathrm{Ba}$ viera, é considerado o grande modelo de sucesso; seguido da Argentina, aparentemente em recuperação, com seus 32 milhôes de habitantes, enquanto o colosso brasileiro, que preenche a maior parte do continente e conta com uma populaçáo de 150 milhóes, náo consegue, ao que pa- 
rece, sustentar-se sobre as próprias pernas em termos de economia de mercado. Isso não deriva somente da falta de vontade política de fazer reformas, mas também do fato de as reformas neoliberais nem sequer conseguirem alcançar estruturalmente os grandes territórios. $O$ Brasil tem, sim, êxitos em termos de exportaçăo, mas os problemas estruturais do país não conseguem ser resolvidos assim. A má correlação entre uma população reproduzida através da relação com o mercado mundial e aqueles que são excluídos dele fere mais à vista no caso de uma populaçáo de 150 milhóes do que no de 10 a 30 milhóes.

Muito semelhante é a situaçáo na Europa do Leste. Enquanto as esperanças e os êxitos parciais, badalados a não mais poder, se limitam somente à Hungria (10 milhóes de habitantes), à Tchecoslováquia, entrementes dividida em duas (15,6 milhóes de habitantes, dos quais 10,3 milhóes na República Tcheca), e à Polônia (38 milhóes de habitantes), a grande massa territorial e populacional eurasiática (Bálcās, Rumênia, Bulgária, Rússia e inclusive a sua parte asiática), com centenas de milhóes de pessoas, mergulha no caos e na guerra civil: também aí os experimentos neoliberais acabam num vazio.

Mesmo na Ásia pode-se constatar idêntico problema. Segundo um relatório amargamente irônico do Banco Asiático de Desenvolvimento (ADB), sediado em Manila, a Ásia ainda continua sendo - apesar de ter, em parte, elevadas taxas de crescimento -, com 700 milhóes de pessoas abaixo do limite da pobreza, o maior asilo de mendigos do planeta, e continuará sendo assim até a virada do século. Também aí os mais importantes dos recentes modelos de êxito têm um formato liliputeano. Dos quatro famosos tigres asiáticos, Hong-Kong e Cingapura são cidades-estados, que, com 5,9 milhōes de habitantes (Hong-Kong) e 2,7 milhóes (Cingapura), não alcançam sequer a dimensão populacional da Baixa-Saxônia ou de Hessen; Taiwan é uma ilha com 20 milhões de habitantes; a Coréia do Sul, uma península com 42 milhóes. Já o maior dos países do ASEAN distancia-se disso sem a menor esperança, apesar das elevadas taxas de crescimento: na Indonésia (180 milhóes de habitantes), o produto interno bruto jaz, no início dos anos 90 , muito abaixo do de Marrocos e da Namíbia. Fora de qualquer capacidade de desenvolvimento, em termos de economia de mercado, parece encontrar-se Bangladesh (107 milhōes de habitantes). $\mathrm{Na}$ Índia (850 milhōes de habitantes), as tentativas de reforma neoliberais ameaçam fracassar. Os prolegômenos a uma abertura de mercados acabaram arruinando boa parte da classe média por meio de importaçōes baratas, levando, por exemplo, a indústria têxtil à ruína econômica. $O$ enorme reino começa a perder sangue em guerras civis e doutrinas fundamentalistas, que são 
alimentadas pela miséria crescente, ainda que não sejam determinadas exclusivamente por fatores econômicos.

Mesmo o maior colosso da Ásia, a República Popular da China, com 1,2 bilhóes de habitantes, apesar das altas taxas de crescimento e dos recentes êxitos em termos de exportação, não pode ser computada entre os modelos asiáticos de sucesso, embora os ideólogos neoliberais tratem de embolsar enganosamente isso, por causa das reformas de Deng no sentido da economia de mercado. Em 1990, o PIB per capita, ainda estava um terço abaixo do da Indonésia (que é quase igual ao da Índia). Apesar dos elogiados êxitos na exportação, o volume absoluto de exportação da comparativamente ínfima Ilha de Taiwan (Formosa) ainda continua sendo maior que o da República Popular da China inteira. Mais de $60 \%$ da população chinesa com poder aquisitivo está sendo empregada de modo subprodutivo em atividades agrárias; uma elevação da produtividade agrária, de maneira a poupar trabalho através da maior utilização de capital tecnológico, acabaria levando (sem considerar aí os custos de capital) a uma explosão do índice de desemprego, já que o setor industrial não tem capacidade equivalente de absorver mão-deobra.

E mesmo dentro da própria indústria, as reformas realmente profundas em termos de economia de mercado limitam-se, por necessidade, ao sul da China, e lá sobretudo às zonas de economia especial, como Chenzhen. O ceticismo de Erwin Wickert (1982), o antigo embaixador alemão em Pekin, precisa ser, portanto, compartilhado: "Sim, de fato, o setor livre se expande, mas não se deixam privatizar as grandes indústrias, com dezenas de milhares de trabalhadores, que continuam, como antes, produzindo com alto déficit mercadorias freqüentemente não comercializáveis... Elas são mantidas somente mediante subvençóes, $\mathrm{e}$ para isso são jogados fora $40 \%$ do orçamento geral da República Popular da China. Elas não podem ser fechadas, pois a manutenção dos desempregados seria igualmente dispendiosa". Se chegar a tanto, orientada para a exportação em termos de economia de mercado, a reforma pode integrar talvez 50 a 100 milhões de pessoas no sul da China, enquanto mais de um bilhão de chineses nem sequer são atingíveis por esse projeto. O imenso espaço econômico da República Popular da China encontra-se, assim, antes numa transição para a desestabilização do que para o milagre econdmico. Conhecedores da história chinesa consideram possível até mesmo secessões e uma sangrenta guerra civil, em cujo vórtice poderão ser arrastados, então, também Hong-Kong (que, como se sabe, há de perder ainda na década de 90 o seu estatuto de colônia da coroa britânica, vindo a ser incorporada à República Popular da China) e Taiwan. 


\section{Atrás dos bastidores dos modelos de esperança}

De uma perspectiva realista e tomados em sua grandeza real absoluta, os modelos de sucesso e esperança discutidos pelo neoliberalismo, na melhor das hipóteses, podem ser caracterizados, portanto, como pequenas existencias em nichos, e mesmo estes somente são possíveis no contexto da estrutura global de déficit monetário, ou seja, de geraçáo improdutiva de dinheiro, que já começa a oscilar de um modo alarmante. É uma produção silenciosa de ideologia catapultar tais modelos mecanicamente para os grandes territórios e as grandes massas populacionais na Ásia do leste e do sul, América Latina e Eurásia (para náo falar na África). E mesmo tais pequenas exceçóes à regra - exceçóes inclusive de dimensóes simplesmente anãs - já se deixam hoje demonstrar, não só teórica, mas também empiricamente, como casos altamente problemáticos. A um exame mais acurado, algumas das proeminentes stories de milagres revelam-se questionáveis, năo só por sua inserçáo na estrutura mundial, mas também por seu problemático processo.

Assim, com os primeiros exitos no processo de reformas econômicas do Presidente Menem na Argentina, o dia foi louvado antes de chegar a noite pelos ideólogos neoliberais. Na Argentina (de um modo semelhante ao México e à Venezuela), náo foi renovada mais que a fachada. O brutal curso de austerity, desde que Menem assumiu o poder, arruinou grandes parcelas da classe média, fazendo explodir para valer a miséria em massa. A decadência a longo prazo pode ser esclarecida por uma comparaçáo numérica, que revela a posiçăo relativa da Argentina: se, em 1950, o país estava no oitavo lugar em termos de PIB per capita, em 1990 ele caiu para o lugar no 84 (Sanches, 1991). Na década perdida dos anos 80, a Argentina foi grandemente desindustrializada. De 1980 a 1985 , a produção industrial caiu $4,4 \% \mathrm{em}$ média a cada ano; no final dos anos 80, ela caiu 4,9\% em 1988, e 8,5\% em 1989 (Banco Mundial, 1992b).

Os modestos êxitos em termos de crescimento no início da década de 90, estatisticamente nem sequer seguros, e a reduçáo forçada da inflação para $2 \%$ ao mês foram obtidos não não só mediante processos de empobrecimento que iráo repercutir a longo prazo: eles podem inclusive revelar-se rapidamente como fogo de palha, pois o saneamento orçamental através do leilão de empresas estatais não deve durar muito tempo, enquanto o dinheiro emergencial assim realocado revoa sobretudo para o consumo de artigos importados ou para a especulação, ao invés de ir para novos investimentos. Quando se afirma que essa situa- 
ção é o início de uma luta pela recuperação, isso equivale a dizer de um boxeador arrasado, cujos ossos foram todos partidos e que abre um olho inchado ao acordar do knock-out, que ele, para consolo geral, já começou a treinar para a próxima olimpíada. $O$ caráter incerto do processo de reestruturaçáo neoliberal pode ser também observado no México, que consegue incorporar, nas promessas da economia de mercado, menos ainda dos seus mais de 86 milhóes de habitantes. Alguns observadores independentes já começam a preocupar-se com o avanço do experimento neoliberal: "O presidente Salinas de Gortari, do México, e o chefe de Estado, Carlos Menem, da Argentina, os brilhantes representantes dessa estratégia, gozam realmente de reputaçáo internacional. No plano interno, adensam-se, no entanto, as contradiçóes" (Kornat, 1992).

Mesmo no Chile, que pretensamente já se encontra além do debate latino-americano, quando encarados de perto, os êxitos parecem muito estranhos. De fato, o Chile pode consignar um enorme crescimento no comércio exterior, no qual, porém, entrementes, o superávit em exportação, depois de um ápice em 1988, já andou caindo novamente. A abertura neoliberal foi, no entanto, conseguida náo só com o maior sacrifício social, como também se encontra muito longe de possibilitar o acesso a um modelo dos tigres asiáticos, de industrialização induzida através da exportação. $O$ Chile não exporta automóveis nem televisores, mas sempre ainda principalmente matérias-primas e produtos industriais próximos à matéria-prima, com um grau relativamente restrito de elaboração. A monstruosa dependência do cobre (o Chile é o maior produtor mundial de cobre) caiu efetivamente, mas, apesar disso, dependendo da cotação no mercado internacional, as exportaçóes de cobre abrangem cerca de $\mathbf{5 0 \%}$ do volume global do que é exportado. A isso soma-se a participação crescente de outros produtos da mineração. Logo depois vêm os derivados da pesca, como peixes frescos, conservas e farinha de peixe, bem como madeira, produtos madeireiros e celulose. $O$ que subiu de modo considerável é a participação das exportaçóes de legumes (Statistisckes Bundesamt, 1991). Apesar da crescente diversificação dos artigos exportados, portanto, não se pode falar, a rigor, de uma industrialização induzida pela exportação: pelo contrário, nessa perspectiva, o Chile tem sido, tanto quanto seus vizinhos, antes parcialmente desindustrializado pelo curso neoliberal.

Feitas com ajuda de capital estrangeiro, a industrialização e a orientação para a exportação da pesca e da elaboração de madeira - dois pilares do milagre cbileno - têm, no plano interno, catastróficas conseqüências sociais e ecológicas. Muitos pescadores nativos precisam desistir devido à destrutiva capitalização das riquezas naturais: "Os resul- 
tados foram, porém, cada vez mais restritos, uma decorrência da pesca predatória na Corrente de Humboldt, rica em peixe, diante da costa do Chile. A mais recente moda em termos de exportaçáo: farinha de peixe, que arrebanhou, no ano passado, a quantia de $\mathbf{4 5 7}$ milhóes de dólares. Mas as redes da frota de pesqueiros não fazem nenhuma diferença ao buscarem os peixes pequenos. A indústria da farinha de peixe ameaça, por isso, toda a reserva de peixes. O que importa é apenas exportar cada vez mais maciçamente. Nos primeiros seis meses de 1989, só a pesca cresceu em $29 \%$. (...) Mas os recordes de exportaçáo deixam arrasados setores na ecologia do Chile: a exportaçáo de legumes baseia-se em imensas monoculturas. No lugar dos até agora 500.000 hectares de mata virgem, vão surgindo desertos de pinhos replantados. $O$ deserto de Atacama, no norte do Chile, deve tornar-se inclusive um depósito de lixo. Com prospectos glamourizados, o Estado andino chega mesmo a oferecer-se como lixeira industrial e urbana" (Germund, 1989). Um efeito secundário do milagre exportativo consiste no fato de certos produtos (sobretudo frutos do mar), que antes eram acessíveis ou disponíveis para todos, serem mantidos longe dos chilenos pobres ou terem se tornado artigos de luxo impossiveis de pagar.

Muito pior que com os modelares discípulos latino-americanos das reformas econômicas neoliberais, anda a coisa com os da Europa do centro-leste. Já as primeiras tentativas de reforma em 1989/90 levaram a devastadoras quebras da produçáo e processos de empobrecimento. Os esperançosos adeptos foram, em poucos meses, lançados de volta diretamente ao status da América Latina. Em 1991, o percurso pelo vale das lágrimas prosseguiu. Em relação a 1990, o produto interno bruto na Hungria caiu mais uma vez em $10 \%$, e na Tchecoslováquia até em $21,2 \%$, depois de já ter decrescido em $24,2 \%$ no ano de 1990 . Na Polônia, o PIB caiu em 9\% e a produçáo industrial em 11,9\%, depois de já ter tido um retrocesso de $24,2 \%$ em 1990 (Weltalmanach, 1993). Essas são quedas jamais antes vistas, e, para superá-las, não seriam necessários somente anos, porém decênios. Em nenhum dos três países a inflaçáo e a dívida externa estáo sob controle, embora a política de austeridade jogue a populaçáo na miséria. Esta parece ser, afinal, a lógica do neoliberalismo: quanto mais saudável a economia, tanto mais doente e pobre a populaçăo humana.

Se é apresentado como um grande êxito que, segundo dados do Departamento Central de Planejamentos da Polônia (CUT), a produção industrial cresceu novamente em $3,5 \%$ no ano de 1992 , então é preciso derivar daí, como na Amércia Latina, a fórmula: um quilômetro para trás, dois passos em frente! Quão lamentáveis e estruturalmente débeis 
são as últimas recuperaçóes pode ser decifrado no predmbulo do milagre polonês: "A ascenção deve-se principalmente a uma evoluçáo positiva nos setores de madeira/papel, minérios e meios de subsistência (o Chile envia saudações!. R.K.)... O governo conta com um crescimento do PIB em 1993 de 2\%. Preocupação acarreta, pelo contrário, o setor da construção, com investimentos ainda em queda. No ano de 1992, afinal,

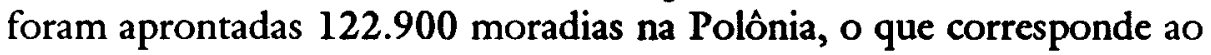
nível de 1957(!). (...) Devido aos empréstimos continuarem sendo ainda muito caros e devido à falta de recursos próprios, os investidores não estão em condiçóes de assumir necessários investimentos de modernização. Além disso, as importaçōes do estrangeiros continuariam a criar dificuldades à indústria nacional. (...) No final do ano, estavam registradas na Polônia 2,5 milhóes $(13,6 \%)$ pessoas como desempregadas (1991: 2,16 milhóes), estando previsto, para dezembro de 1993, que se alcançará a marca de 3 milhôes de pessoas (o que corresponderá a 16\%)" (Handelsblatt, 1993). Mesmo com crescimento contínuo, que é extrapolado mecanicamente, deixando no escuro todas as armadilhas estruturais e intermediadas pelo mercado mundial, os condutores da esperança na Europa do centro-leste poderiam, talvez, alcançar até meados do século XXI o padráo da economia planejada estalinista. Mas que grande êxito é esse!?

Apesar de sua posição, até agora naturalmente muito melhor, a forma de transcorrer o processo econômico também não se coloca de um modo univocamente positivo nos tigres asiáticos. Já que as pequenas cidades-Estados - Hong-Kong e Cingapura - tendem a cair de qualquer maneira fora da concorrência, interessa aí sobretudo a Coréia do Sul. Ao contrário do que diz a lenda fabricada, a ascensão não ocorreu, de jeito algum, de modo contínuo, mas sim com pesadas quebras e rupturas, que apontam de maneira significativa para a fraqueza estrutural. O desenvolvimento foi conseguido com os mais brutais sacrifícios sociais e sangrentas medidas de repressão: "Especialmente foram mulheres e moças mal pagas, que, durante a fase heróica dos anos 60 e 70, produziam a fortuna exportativa em empresas-anãs da indústria têxtil. (...) Órgãos de segurança do Estado reprimiam toda e qualquer resistência contra essas formas de exploraçáo..." (Pohl, 1991). Depois de ter sido, dessa maneira, forçada uma ofensiva exportadora à base da indústria leve, os custos de capital, para os investimentos no âmbito de novas indústrias pesadas, de máquinas e de produção de automóveis, ameaçavam levar ao desastre: "A altíssima carência de capital para tanto exigia demais dos orçamentos públicos, razáo pela qual se tornou necessário assumir enormes créditos no exterior, que levaram, por fim, a uma imensa dívida externa. Com isso, elevou-se a inflação; o que, junto com 
fenômenos generalizados de recessão econômica mundial no final do decênio (crise do petróleo, elevaçáo internacional dos juros), conduziu a uma crise econômica e política interna, em cujo transcurso chegou a ocorrer, em 1979, o assassinato do general Park. Em 1980, registrou-se pela primeira vez na história do pós-guerra um crescimento econômico negativo de 4,7\%" (Statistisches Bundesamt, 1992).

Mostrou-se, portanto, dramaticamente a dependência com relação à conjuntura ocidental, bem como o problema de custos de capital dificilmente controláveis, ameaçando lançar a Coréia do Sul na situação das economias perdedoras e em bancarrota. É verdade que o país conseguiu ainda uma vez tirar a cabeça da forca: "Nos anos de 1986 a 1989, ocorreu - apoiado por um desenvolvimento favorável do câmbio um boom exportativo e econômico. A balança de pagamentos da Coréia assinalou pela primeira vez superávits, através dos quais tornou-se possível uma rápida diminuiçăo da dívida externa" (Statistisches Bundesamt, 1992). Mas com isso não foram, de maneira alguma, eliminados os problemas estruturais da dependência. Pode ser tudo, menos ocasional, que a aparente salvaçáo e o desenvolvimento do modelo exportador coincida justamente com a economia-vudu dos reaganomics nos Estados Unidos. Só as explosóes interna do déficit e a externa da dívida é que possibilitaram a exportação em máo única através do Pacífico. $O$ término da era republicana e a saída pouco honrosa do Presidente Bush mostram que essa máquina miraculosa está hiperaquecida e já começa a bater biela. Isso também a Coréia do Sul passa naturalmente a sentir. $O$ descenço conjuntural no Ocidente fez com que as exportaçōes já passassem a cair. Os problemas de custos de capital sobem de novo verticalmente, bem como a inflaçăo e a dívida externa. Os investimentos externos diretos na Coréia do Sul, porém, estáo regredindo desde o final dos anos 80, bem como a entrada de capital estrangeiro (de 1,28 bilhões de dólares em 1988, para 1,09 bilhŏes em 1989 e apenas 663 milhóes em 1993).

Agora ameaçam também inclusive os custos de uma reunificação com a falida Coréia do Norte, que, num primeiro momento, são avaliados como năo inferiores a $\mathbf{5 0 0}$ bilhóes de dólares. Em vista da experiência alemã, só esse problema poderá significar o golpe de morte para o modelo Corcía do Sul se os mercados de exportaçáo entrarem ao mesmo tempo em retraçáo. A reorientaçáo para os mercados do leste europeu, táo eufórica num primeiro momento, pois deveria livrar a exportação sul-coreana de sua dependência unilateral, mostrou ser ilusória, tanto quanto as correspondentes esperanças na Europa ocidental. Os Estados membros da antiga União Soviética, incapazes de pagar, já estão com 
vários bilhóes de dólares no vermelho junto à Coréia do Sul. Em 1992, a situação conjuntural continuou piorando, apesar de, nominalmente, as taxas de crescimento só terem decrescido bem pouco: "De fato, muitas empresas ainda brilham com vendas crescentes, no entanto as margens de lucro caem ameaçadoramente em alguns setores. Mesmo os lucros dos exitosos produtores coreanos de automóveis mal conseguiram amealhar um terço no último ano. Em ramos econômicos de trabalho intensivo, bancarrotas estão na ordem do dia. De 845 fábricas de calçados, 124 cessaram suas atividades no ano passado" (Wirtschaftswoche, 1992). Também o modelo exportador sul-coreano pode sempre ainda cair no abismo, como o governador do banco central alertava cheio de premonições.

\section{O término da conjuntura deficitária no Japão e na Alemanha}

Os restos de normalidade em termos de economia de mercado, que, para a maioria global, já se transformaram $\mathrm{em}$ pesadelo social $\mathrm{c}$ ecológico, estão como um todo pendurados no fio de linha do crescimento aparente, à base de déficit, nos países capitalistas centrais. A ruptura do dique de uma crise geral creditícia e financeira, que já tem ameaçado diversas vezes, pôde ser evitada até agora, embora com dificuldades. A repercussão na conjuntura mundial ainda não conduziu à depressão generalizada, mas a uma estagnaçáo que se arrasta de modo renitente. Um ator principal após o outro revela sinais de estafa.

O Japão não se choca tão-somente com a barreira de sua espoliaçăo de estruturas de fornecedores: com a queda dos preços imobiliários e do mercado de açóes, vem-lhe sendo arrancado também o segundo pé de barro. Os fenomenais êxitos japoneses nas últimas décadas náo se explicam apenas a partir de sua organização do trabalho, mas também a partir da maior orgia especulativa na história dos mercados financeiros até hoje. Só no ano de 1987, o Japão, através da elevação especulativa dos preços das ações e dos imóveis, passou a calcular-se mais rico em cerca de 3 trilhóes de dólares (\$3.000.000.000.000!). Os valores imobiliários ficticiamente inchados têm servido como garantias emprestáveis, com que o curso das ações é aquecido. A bolsa transformou-se, assim, num self-service financeiro da indústria e numa fonte aparentemente inesgotável de refinanciamentos. Em outras palavras: investimentos imensos, que conduziram o sucesso exportativo japonês para além de qualquer medida, puderam ser concretizadas praticamente por uma 
tarifa zero, assim como o controle maciço de firmas estrangeiras e até mesmo certas orgias de compras no mercado internacional de arte. Uma parte considerável da mui decantada capacidade inovativa japonesa e alegria em investir repousa apenas em vento quente.

Essa maravilhosa peça de pilantragem financeira (em que, năo por acaso, a máfia japonesa teve abundante participação) não podia, naturalmente, continuar sem punição. A queda abrupta do mercado imobiliário e do curso das açóes em mais da metade (o índice Nikkei caíu até o início de 1993 de 38.000 para cerca de 16.500 pontos) já deveria ter levado a uma pesada crise financeira, que só o gerenciamento financeiro conseguiu empurrar adiante com a barriga através de escabrosas manipulaçóes. Em meados de 1992, foi fundada uma sociedade nacional de captação de recursos, para créditos periclitantes de não-bancos, que, a rigor, há muito já estavam insolventes (principalmente firmas no setor de imóveis, construçáo civil e serviços). Mesmo assim, rola a onda de falências: "A estatística de concordatas de 1992, publicada pelos destacados escritórios de informações Teikoku Data Bank e Tokyo Shoko Research, revela um crescimento dos casos de concordatas em cerca de 14.200 (um aumento de 32\%). (...) De um modo especialmente intenso cresceu o número das grandes concordatas, com um volume de dívidas de, pelo câmbio, mais de 13 bilhóes de marcos alemáes ( 950 casos, um aumento de 33\%). (...) Ambos os escritórios de informação esperam, para a primeira metade deste ano, (...) uma seqüência nessa involuçáo. Só em dezembro de 1992, entraram 1454 empresas em concordata. (...) Marcante foi, aí, especialmente o aumento das empresas que caíram em dificuldades na área da produção industrial" (Handelsblatt, 1993). Programas conjunturais do governo, em rápida sucessão, no valor de várias centenas de bilhōes de marcos alemáes, não serviram praticamente para nada mais que apoiar a especulação despencante. Pela primeira vez, desde o final da guerra, desenha-se uma recessão pesada e profunda na economia japonesa. A Nippon passou a depender de um modo estonteante de processos financeiros especulativos, e tratou de procurar o impossível: ou seja, superar os processos financeiros especulativos de conseguir dinheiro através da garantia governamental da megabancarrotação. Esta seria, seguramente, a quadratura do círculo.

Igualmente ruim, ainda que por outras razōes, encontra-se, entrementes, a situação do matador em termos de economia mundial, a Alemanha. Nela, é menos a especulação, e mais o desastre econômico da reunificação alemã, que arrastou para a beira do desastre a estrutura deficitária teuta e de toda a Europa ocidental. A transferência líquida anual improdutiva, de cerca de 200 bilhōes de marcos alemáes, para a 
Alemanha oriental, incorporada, mas não mais rentavelmente reprodutível, obrigou o Bundesbank (Banco Federal) alemão a uma política de juros elevados dentro da crise conjuntural européia, fazendo oscilar fortemente o sistema monetário europeu (EWS). As moedas dos países vizinhos, ficaram sob pressão, a Itália e a Grā-Bretanha já tiveram de sair da coligação cambial. Como o marco alemão é a principal moeda européia, os países vizinhos, mediante ousadas manobras da máquina de fazer dinheiro (queda dos juros), têm ficado impedidos de salvar as conjunturas internas em queda. A leve baixa de juros do Bundesbank, no início de fevereiro de 1993, não foi mais que um gesto teatral, incapaz de eliminar do planeta o problema estrutural. Depois de a reunificação alemã - no início através da abertura da Alemanha oriental e da alteração da moeda - ter desencadeado um fogo de palha conjuntural em toda a Europa, ela se transforma agora, pelo contrário, em uma sobrecarga para toda a Europa. Especialmente a Itália e a Espanha, com imensas dívidas públicas e dívidas externas, encontram-se sob pressão: muitas firmas já não conseguem mais pagar empréstimos de volta, nos bancos se acumulam créditos podres. A mesma situação se exacerba na Grã-Bretanha, que não consegue mais sair de sua recessão estrutural, que já vem de anos. Como, porém, a maior parte das exportaçóes alemás vai para o espaço da Comunidade Européia e da EFTA, a falência da estrutura deficitária européia, indiretamente autoprovocada pelo casório da reunificação, reflui, desde o inverno de 1992/93, com força total sobre a conjuntura alemã.

\section{Os Estados Unidos: nenhuma nova locomotiva da conjuntura}

Nessa situação emergencial, a doente e doentia potência dos Estados Unidos precisa ser, contra a melhor consciência, novamente conclamada como salvadora da conjuntura mundial. Também lá, no entanto, a especulação com açóes e imóveis levou, de um modo semelhante ao Japão, a um endividamento estrutural da maioria dos grandes setores empresariais. Acresce-se a isso o déficit orçamentário do Estado, que há muito já se encontra fora de controle e que, não em última instância, foi causado pelos gastos de ser a poténcia mundial e pelo papel de gendarme do universo assumido pelos Estados Unidos. Sobretudo, no entanto, atuam como entraves conjunturais a baixa quota de poupança, bem como o elevado endividamento dos orçamentos domésticos norte-americanos, cujo volume transcende a renda global disponível. A dívida dos 
orçamentos domésticos corresponde atualmente a 4 trilhóes (4.000.000.000.000) de dólares, o dobro de 10 anos atrás. Cada orçamento doméstico está com uma dívida média de 70.000 dólares. Que lastro de chumbo isso significa, para a conjuntura, pode ser mensurado pelo fato de os orçamentos domésticos corresponderem a $70 \%$ do produto social bruto dos Estados Unidos!

Nos mercados internacionais, os Estados Unidos são, porém, quase incapazes de concorrer, devido à falta de qualidade e à produtividade decrescente. Assim, as exportaçóes somente conseguem ser elevadas através de quedas no curso do dólar, o que barateia as mercadorias norte-americanas no exterior: um método, no entanto, pouco sério e extremamente incerto, com o qual uma potência mundial também não consegue se sustentar na superfície por longo tempo. Debilidade exportativa e, apesar disso, crescente inserção na economia mundial, endividamento estrutural global e falta de formaçáo interna de capital, já degradaram há muito os Estados Unidos a uma poténcia mundial dependente do exterior, que continua condicionada à entrada de artigos estrangeiros e de capital monetário de fora. No breve período neoliberal dos anos 80, os déficits comerciais e de balanço de capital acumularam-se até alturas estonteantes.

Não se consegue, portanto, discernir como, justamente os Estados Unidos, podem vir a ser a nova locomotiva da conjuntura mundial endividada e deficitária. Apesar de toda uma série de quedas nas taxas de juros, a administração Bush não conseguiu mais salvar-se, pois a reprodução, profundamente endividada em todos os setores, já não conscgue mais ser redimida decisivamente através de novas injeçōes de dinheiro. Um reiterado deficit spending e o fomento de mecanismos de gerar dinheiro através do sistema bancário resolvem táo pouco quanto elevar as doses no estágio final do alcoolismo. Já que a reprodução endividada não mais torna rentáveis investimentos produtivos adicionais, engatar a geraçáo de dinheiro através do banco monetário norte-americano ( $\mathrm{fed}$ ) fez somente com que fluísse fresh money na especulaçáo com açóes (nesse sentido, de um modo bem parecido com o Japão). $O$ índice Dow-Jones de New York subiu assim, paradoxalmente, a novos recordes, justamente no contexto de uma crise conjuntural.

Também o novo presidente, Bill Clinton, não pode ser o santo milagreiro, como ele apressadamente foi festejado. Um desendividamento real e uma desmontagem decidida dos déficits somente levariam, enquanto choque deflacionário, tanto mais rápido à catástrofe da depressão. A reconstrução da capacidade de concorrência, especialmente da esgotada infra-estrutura, precisa ser calculada não para anos, e sim 
para décadas. Também Bill Clinton não consegue superar, com um condão mágico, a ruinosa política de desregulamentação da era republicana. Por causa das condiçôes estruturais, a curva conjuntural nos Estados Unidos há de, na melhor das hipóteses, ficar achatada, não sendo mais possível um reaquecimento cíclico duradouro e sustentável. Muito menos se pode esperar que os Estados Unidos venham a arrastar para um novo ascenso a conjuntura deficitária global. À medida em que, com dificuldades, a conjuntura interna norte-americana consegue ir se arrastando, os Estados Unidos hão de envolvê-la dessa vez com fortes medidas protecionistas. $O$ governo Clinton, que náo está mais tão fortemente atormentado por ideologias neoliberais, já sinalizou de antemão uma radical mudança de curso nesse sentido.

Atingidos por isso hắo de ser sobretudo o Japão e seus parceiros menores no leste asiático. Os empresários japoneses, que não só conseguiram as suas pouco sérias vantagens concorrenciais através de dumping sócio-industrial e de manipulaçóes financeiras, procuram agora também o compadrio para exportarem a sua inevitável recessáo. Os excedentes comerciais japoneses estão a explodir desde 1991, justamente em meio à crise, porque a indústria japonesa procura atualmente inserir os seus grandes investimentos da década passada, financiados manipulativamente, para um novo dumping de preços nos mercados internacionais, a fim de repassarem para o exterior a crise doméstica. $O$ recorde no excedente da balança de pagamentos, em 1991, de 103 bilhōes de dólares, foi elevado para 182,6 de dólares em 1992: o prognóstico prevê, para 1993, cerca de 140 bilhóes de dólares (se chegar a tanto). Esse curso de kamikase não pode ser mantido nem com relaçáo à Europa nem aos Estados Unidos. Certamente, no contexto da globalização progressiva, existe todo um leque de dependências mútuas, mas a radicalizaçáo da contradiçáo intrínseca à economia global de mercado só pode acabar degenerando $\mathrm{em}$ sacanagens recíprocas, sem respeitar nada nem ninguém. Os grandes perdedores podem vir a ser o Japáo e os newcomers do leste asiático, uma vez que eles, por causa de sua debilidade importativa, não seriam capazes de ameaçar com um protecionismo inverso nem possuem, como ultima ratio, um potencial de intimidação militar digno de menção. No entanto, a retirada do capital de crédito japonês poderia desencadear uma depressão financeira generalizada nos Estados Unidos.

É difícil predizer se o final da conjuntura deficitária global embocaria abruptamente, com grandes catástrofes financeiras, numa depressão mundial, ou se iria percorrer, mais uma vez, uma fase mais longa de estagnação e manipulação. A contradição lógica inerente ao sistema 
de mercado não se deixa, no entanto, eliminar. Dever-se-ia supor que, nessa situação, seria adequada uma nova crítica à socialização em termos de economia de mercado, que, nessa fase do desenvolvimento mundial e da redeficaçáo internacional, já nada mais teria a ver com os pré-diluvianos sistemas de planejamento estatal do falido socialismo de modernizaçăo, nem mais poderia seguir a isso nenhum modelo de justa troca de equivalentes. Pensar em termos além da economia de mercado, isso nos foi, no entanto, há pouco rigorosamente proibido por filósofos franceses, reformistas poloneses e realistas alemães. No atual clima espiritual, não seria bom para a reputaçáo ferir essa nova crendice ideológica. Assim sendo, não parece restar nada senão exigir um otimismo impiedoso em torno da economia de mercado, de preferência se de origem norte-americana, pois é, de longe, o mais barato. Don 't worry, be bappy.

\section{Notas}

1 Mancur Olson. Die Logik des kollcktiven bandelns. Kollektive Gïter unddie Theorie der Gruppen, Tübingen, 1968 (inglês 1965); Mancur Olson. Auftieg und Niedergang pon Nationen. Ökonomisches Wachstum, Stagflation und soztale -Strurbeit; Tübingen, 1985 (inglés 1982). Para essa discussão: Klaus Schubert (org.). Leistungen und Grenzen politisch-ökonomischer Theorie. Eine kritische Bestandsmufralbme zas Mancur Olson, Darmstadt, 1992.

2 Que o embalo dos anos 80 não era um crescimento auto-sustentado da indústria e do setor de serviços, tornou-se visível como desvinculafrío dos mercados financeiros com relação aos mercados de mercadorias. A expansão do crédito foi muito além da expansão da produção real de mercadorias, o que aponta para o crescente endividamento dos produtores e consumidores.

3 Essa separaçâo volta até Karl Marx, cuja obra principal se ocupa com a lógica do capital em geral. Nesse nível de abstraçáo, năo tem maior relevância a questão dos estágios de desenvolvimento e processos de globalização, ou serve apenas de ilustração.

4 Isso envolve tanto contribuiçóes mais antigas quanto mais recentes do marxismo ocidental. Confronte-se, por exemplo, Paul Mattick. Marx und Keynes. Die Grenzen des "gemisclbten Wirtschaftssystems", Frankfurt a.Main, 1971; ou Joachim Hirsch e Roland Roth. Das neuc Gesicht des Kupitalismus. Vom Fordismus zsum Pos-Fordismus, Hamburg, 1986.

5 A transição encontra-se em Dieter Senghaas. Von Eucropa Vermen. Entwicklungsgeschichtliche Betrachtungen, Frankfurt a.Main, 1982. Além disso, compare-se Ulrich Menzel e Dieter Senghaas. Europas Entwicklung und die Dritte Welt. Eine Bestandaufnabme; Frankfurt a. Main, 1986. Entrementes mais uma vez Ulrich Menzel. Das Ende der Dritten Welt und das Scbeitem der groÂen Theoric, Franlfurt a.Main, 1992.

6 O conceito de sistema mundial (Weltsystem) assume um posto central sobretudo nos 
livros e ensaios de Immanuel Wallerstein. A discussão, levada a efeito no âmbito da língua inglesa, somente foi recebido explicitamente na Alemanha no início da décade de 80. Conf. quanto a isso Immanuel Wallerstein. "Aufstieg und künftiger Niedergang des kapiralistischen Weltsystems. Zur Grundlegung vergleichender Analyse" in Dieter Senghaas (org.). Kapitalistische Weltökonomic. Kontropersen über ibren Ursprung und ibre Entwicklungsdynamik, Frankfurt a.Main, 1979. Além disso, André Gunder Frank. Abbängige Akkumulation und Unterentwicklung, Frankfurt a. Main, 1980 (ingl. 1978). Dados bibliográficos mais completos sobre todo o debate encontram-se em Ulrich Menzel. Geschichte der Entwicklungstheorie. Einfiilsrung und systematische Bibliographie, Hamburg, 1993.

7 Conf. quanto a isso Elmar Altvater. Der Preis des Woblstands oder Umweltplïnderung und newe Welt(un) ordnung, Münster, 1992.

8 Dados segundo Ulrich Menzel, " Von der industriellen zur finanziellen Supermache", in Ulrich Menzel (org.) Im Scbatten des Siegers: JAPAN, v. 3, Economia e Polírica, Frankfurt a. Main, 1989. Menźzel encara, no entanto, essas disparidades evidentes não como sintoma da crise, mas como "marcha triunfal japonesa".

\section{Referências bibliográficas}

AFHELDT, Heik. "Dornröschen in Drachenkleid", in Wirtschaftswoche n. 4, de 22 Jan. 1993.

ALTVATER, Elmar. Der Preis des Woblstands oder Ummeltplünderung und neuse Welt(un)ordnung, Münster, 1992.

BANCO MUNDIAL. Relatório do desenvolvimento mundial - 1992. Tópicos: Departamento Federal de Estatística, Relatório nacional Argentina 1992.

BANCO MUNDIAL. Relatório do Desenvolvimento Mundial - 1992. Dados marcantes do desenvolvimento mundial.

DADOS CONJUNTURAIS de 1991 para a Europa Oriental, in Fischer Weltalmanach 1993.

FRANK, André Gunder. Abluängige Akkumulation und Unterentwicklung, Frankfurt a. Main, 1980 (ingl. 1978).

GERMUND, Willi. "Elend auf den zweiten Blick", in Die Zeit, de 15 Dec. 1989.

HANDELSBLATT de 22/23 Jan. 1993.

HIRSCH, Joachim \& ROTH, Roland. Das neue Gesicht des Kapitalismus. Vom Fordismus zum Pos-Fordismus, Hamburg, 1986.

KORNAT, Gerhart. "Lateinamerika - Unsicherer Musterschüler", in Handelsblatt de 4 Mar. 1992.

LUTZ, Burkart. Der kurze Traum immerwäbrender Prosperitüt, Eine nowe Interpretation der industriell-kapitalistischen Entwicklung in Europa des 20. Jabrbunderts. Fránkfurt a.Main, 1984.

MATTICK, Paul. Marx und Keynes. Die Grenzen des "gemischten Wirtschaftsyystems". Frankfurt a.Main, 1971.

MENZEL, Ulrich \& SENGHAAS, Dieter. Europas Entwicklung und die Dritte Welt. Eine Bestandaufrnabme. Frankfurt a. Main, 1986. 
MENZEL, Ulrich. " Von der industriellen zur finanziellen Supermachr", in Ulrich Menzel (org.) Im Sclsatten des Siegers: JAPAN, v. 3, Economia e Política, Frankfurt a. Main, 1989. 1992.

Das Ende der Dritten Welt und das Sclocitern der groÂen Thcoric, Frankfurt a.Main,

. Geschiclste der Entwicklungsthcorie. Einfilbrung und systematische Bibliograpbie, Hamburg, 1993.

OLSON, Mancur. Auftieg und Niedergang von Nationen. Ökonomisches Wachstiem, Stagflation und soziale Starrlseit. Tübingen, 1985 (inglês 1982).

Die Logik des kollektiven bandelns. Kollektive Güter unddie Theorie der Gruppen, Tübingen, 1968 (inglês 1965).

POHL, Manfred. " Entwicklungsstrategien, wirtschaftlich-technologischer Fortschritt und politische Implikationen: Das Beispiel Südkorea", in Werner Draguhn (org.) Asiens Sclswellenlïnder: Dritte Weltwirtsclınftstegion? Mitteilungen des Institus für Asienkunde, Hamburg, 1991.

SANCHES, Roberto. " Zwischen Afrika und Dallas" in iln, Zeitsclsrift der Informationsstelle Latcinammerika, dez.,1991.

SCHUBERT, Klaus (org.). Leistungen und Grensen politisch-ökonomischer Theorie. Eine kritische Bestandssufnabme zu Mancur Olson, Darmstadt, 1992.

SCHUMPETER, Joseph. Kapitalismus, Sozialismus und Demokratic, München, 1950 (ingl. 1943).

Konjunkturzyklen, 2 v. Göttingen, 1961 (ingl. 1939).

Theoric der wirtschaftlichen Entwicklung, München/Leipzig, 1912.

SENGHAAS, Dieter. Von Europa Iornen. Entwicklungsgesclsichtliche Betrachtungen, Frankfurt a.Main, 1982.

STATISTISCHES BUNDESAMT, Länderbericht Chile 1991.

Länderbericht Korea, Republik, 1992.

WALLERSTEIN, Immanuel. "Aufstieg und künftiger Niedergang des kapitnlistischen Weltsystems. Zur Grundlegung vergleichender Analyse" in Dieter Senghaas (org.). Kapitalistische Weltökonomie. Kontroversen über ibren Ursprung und ibre Entwicklungsdymamik, Frankfurt a.Main, 1979.

WICKERT, Erwin. "Das pazifistische Jahrhundert, China und Europa", in Freankfiurter Allgemeine Zeitung, de 4 Mar. 1992.

WRTSCHAFTSWOCHE, n. 19, de 1 May 1992.

\section{Resumo}

Com o fracasso do socialismo de Estado na Europa, o neoliberalismo apresenta-se como panacéia universal, mas não tem conseguido resolver muitos problemas práticos e é problemático em seus "milagres", feitos à base de salário barato, trocas assimétricas, créditos artificiais e destruiçăo ecológica. Na teoria é incapaz de perceber as contradiçóes estruturais do capitalismo. Como a economia já está internacionalizada, vem sendo gestada uma crise geral. Os Estados Unidos nảo podem tornar-se novamente a locomotiva da economia mundial, pois sun dívida privada duplicou nos últimos 10 anos, atingindo a cifra média de 
\$70.000 por tàmilin, enquanto as exportaçóes do país só são mantidas com a queda do dólar no mercado internacional. Japão e Alemanha cresceram à base de créditos artificiais, sem aumento proporcional na produção. Os países sul-americanos nảo têm conseguido desenvolver a capacidade de concorrência internacional dos tigres asiáticos, mas estes não thes podem servir de modelo: o Brasil é diferente da Coréia, pois não se encontra na vizinhança de um país desenvolvido como o Japão, a sua população é maior e o seu mercado interno potencial é mais extenso. As teorias da dependência insistiram na concepção de trocas assimétricas e não consideraram suficientemente as contradiçóes e limites do capitalismo, por isso muitos dos seus intelectuais passaram facilmente a defender teses e práticas neoliberais. Há hoje uma barreira para pensar um modelo alternativo ao neoliberalismo vigente, embora sua fallha obrigue a isso.

\begin{abstract}
With the end of state socialism in Europe, neuliberalism is presented as an universal solution, but it can not resolve many practical problems and its " miracles" are very problematic, because of low salaries, asymmetrical exchanges, artificial credits and ecological destruction. Its theory can not elaborate the structural contradictions of capitalism. Economy is internationalised, ir is growing up a general crisis. The United States can not be again the locomotive of international economy, because its private debt has duplicated in the last 10 years and reacches in average $\$ 70.000$ per family and export can just be maintained with the devaluation of the dollar. Japan and Germany have developed through artificial credits, without a proportional increase in production. The latin-american countries could not increase their participation in the international market like the asiatic tigers, but those can not serve them as models: Brazil is not like Corea, has not a very developed neighbour like Japan, has a bigger population and a potentially great internal market. The theories of dependence have insisted on the asymmetrical exchanges, but have not considered enough the intrinsical contradictions and limits of capitalism. So, many dependentists are now defending the theories and practice of neoliberalism. Nowadays it is difficult to think an alteruative model to the dominant neoliberalism, but its failure makes it necessary.
\end{abstract}

Robert Kurzz, filósofo alemão, é coeditor da revista "Krisis" e publicista autônomo. Recentemente foi lançado no Brasil a tradução do seu livro "O Colapso da Modernização" (Editora Paz e Terra).

Palestra feita pelo autor em 15 de abril de 1993, na Escola de Engenharia de São Carlos da USP. O evento foi organizado pela Área de Política Científica e Tecnológica do IEA e pelo Instituto Goethe.

Tradução de Flávio R. Kothe. O original em alemão - "Die Lichter Des Marktes Verloschen" - encontra-se à disposiçăo do leitor no IEA para eventual consulta. 